\title{
Gözlerimi Kaparım Vazifemi Yaparım ve Özne-İktidar İlişkisi
}

\section{Veli íNCE*}

\begin{abstract}
ÖZ
Insanlar toplumları inşa ederken ortak bir yaşam düzeni kurmayı hedeflerler. Bu ortak yaşam düzeni belli bir süre sonra kendini kabul ettiren bir mekanizma haline gelmiştir. Bu süreçte öncelikle teolojik temelli bir ön kabul düzeni kurarken sonra aklın ön plana alındığı bir ön kabul düzeni inşa edilir. Her iki düzende de insanın birey olmasının engellendiği ortaya çıkar. Nitekim iki medeniyet de kendi istekleri doğrultusunda biçimlendirdiği bireyler yaratmayı hedefler. Bu durum karşısında kendi ontik yapısını inşa eden bireyler toplum tarafından yabancılaştırılır, bu yabancılaştırma sistematik düzeyde işletilerek bireyin ontik yapısı ehlileştirilmeye çalışılır. Bu durum istenen düzeyde gerçekleşirse toplum tekrar kabul mekanizmasını çalıştırır. Ĕ̆ger istendik özne olunmazsa sıkıntı, bunalım hali ile yaşamaya mahkûm edilirler. Bu mahkûmiyet süreciyle birlikte kendiliğinin farkına varan birey bu süreçten sonra istese de istendik özne haline gelemez. Toplumla birey arasında oluşan bu çatlak belli bir süre sonra bireyi mücadele etmeye zorlar, bu mücadele önce pasif isyan biçiminde olsa da ontik serüven sayesinde isyana ve bireyin inşasına kendini bırakır. Kendini inşa etmeye başlayan birey öncelikle toplumsal normlar ve kendisi arasındaki uçurumu anlamaya çalışır. Uzun bir anlama serüveninden sonra bu durumun gerçekleşmeyeceğini anlar. Çünkü çağ itibariyle modernleşen toplumlar insanı bireysel yolculuktan alıkoymakta ve tekdüzeleştirmektedir. Bu durumun farkına varan birey akıl ile ruh arasında sıkışıp kalacak, her ikisinden de istediğini alamayacaktır. Modern toplumların yaratmaya çalıştı̆̆ bireyler, adeta bir makine gibi yaşamaya zorlanmakla birlikte isyan halinde deli yaftası adı altında akıl hastanelerine kapatılacaklardır. Nitekim ak1l hastanelerinin de aslinda bir tedavi merkezinden ziyade modern toplumların sosyolojik olarak oluşturduğu kurumlar olduğu burada ortaya çıkar.
\end{abstract}

Öğretmen-Doktora Öğrencisi, Milli Eğitim Bakanlığı-Eskişehir Osmangazi Üniversitesi, Sosyal Bilimler Enstitüsü, Türk Dili ve Edebiyatı Anabilim Dalı, Eskişehir/Türkiye 
$\mathrm{Bu}$ sosyolojik kurumun yegâne görevi modern toplumun kurallarına uymayan bireyleri bir uyum sürecine tabii tutarak normalleştirmedir. Normal yani doğduğu andan itibaren modern toplumun kurallarını ön kabulle hayatına katan bireylerin reddiyle oluşacak kaotik durum böylece engellenmiş olacaktır. Fakat engellenen ve tekdüzeleşen birey bu süreçle birlikte yaratıc1lı̆ını kaybederek insanoğlunun en önemli özelliği olan soru sorma ve cevap arayıp bulma dürtülerinden de olacaktır. Böylece kendi olamayan birey kendine ait olmayan aslında soyut olan kuralların var ettiği toplumda yaşamak zorunluluğu yaşar. İster istemez bu yapay toplum karşısında farkındalığı olan bireyler kendini bir acı içinde bulsa da asıl sıkıntının toplumlar içinde yalnız kalarak veya yalnızlaştırılarak yaşamak ile yüzleşmek zorunda kalınması fikrini içselleştirir. Bu çalı̧̧mada istendik özne yapılmak istenen yani gözlerini kapayıp vazifesini yapması beklenilen bireyin toplumsal, edebi izleri Haldun Taner'in Gözlerimi Kaparım Vazifemi Yaparım adlı eserinden hareketle sürülecektir.

Anahtar Kelimeler: Modernizm, toplum, isyan, mücadele, iktidar, özne, Haldun Taner 


\title{
Gözlerimi Kaparım Vazifemi Yaparım and The Relationship Between Subject And Power
}

\begin{abstract}
When people build societies, they aim to establish a common life order. This common life order has become a mechanism that makes itself accepted after a certain period of time. In this process, firstly, while establishing a theological-based pre-acceptance order, then a pre-acceptance order is built in which the mind is in the foreground. In both orders, it turns out that the human being is prevented from being an individual. As a matter of fact, both civilizations aim to create individuals that they shape according to their own desires. In the face of this situation, individuals who build their own ontic structure are alienated by the society, this alienation is operated at a systematic level and the ontic structure of the individual is tried to be tamed. If this happens at the desired level, the society runs the readmission mechanism. If the desired subject is not taken, they are condemned to live in a state of distress and depression. With this imprisonment process, the individual who becomes aware of himself / herself cannot become the desired subject even if he / she wants to. This crack between the society and the individual forces the individual to struggle after a certain period of time, although this struggle is in the form of passive rebellion, it leaves itself to the rebellion and the construction of the individual, thanks to the ontic adventure. The individual who starts to construct himself tries to understand the gap between social norms and himself. After a long journey of understanding, he realizes that this will not happen. Because the societies that have modernized as of the age keep people from individual journeys and make them monotonous. The individual who realizes this situation will be stuck between the mind and the soul and will not be able to get what he wants from both. Individuals that modern societies are trying to create will be forced to live like a machine, but will be locked up in mental hospitals under the name of insane in rebellion. As a matter of fact, it is revealed here that mental hospitals are in fact institutions formed sociologically by modern societies rather than a treatment center. The sole task of this sociological institution is to normalize individuals who do not conform to the rules of modern society by subjecting them to a process of adaptation. Normally, the chaotic situation that will occur with the rejection of individuals who have pre-accepted the rules of modern society from the moment of their birth will be prevented. However, the prevented and monotonous individual will lose his creativity with this process and will also be the urge to ask questions
\end{abstract}


and seek answers, which are the most important characteristics of human beings. Thus, the individual who cannot be himself has to live in a society created by the abstract rules that do not belong to himself. Although individuals with awareness of this artificial society inevitably find themselves in pain, they internalize the idea of having to face living alone or being isolated in societies. In this study, the social and literary traces of the individual, who is expected to be the desired subject, that is, he is expected to close his eyes and do his duty, will be drawn on the basis of Haldun Taner's work, Gözlerimi Kaparım Vazifemi Yaparım.

Keywords: Modernism, society, revolt, struggle, power, subject, Haldun Taner 


\section{Giriş}

$\dot{\mathbf{I}}$ nsanoğlu topluluk halinde yaşamaya başladığından itibaren kendine bazı kurallar koymaya ve bunlara nispeten uymaya, uymadığı hâlde ardından gelecek olan yaptırıma göğüs germeye veya bu yaptırımın karşısında olmaya hedeflenen davranışlar göstermiştir. Bununla birlikte çeşitli toplumsal düzenler, yönetimler ve ilişkiler kuran zamanı geldikçe bunu yıkan yenisi inşa eden bir varlık olan insan, yönetim konusunda genellikle teolojik bir argümandan beslenerek topluluklar kurmuştur. Tanrı temelli yönetim biçimleriyle birlikte ilahi yönetim metaforu üzerinden okumaya gayret ettiğimiz bu bireyler öznesi olamadıkları topluluğun birer ferdi olmaktan öteye gidememişlerdir. Tanrısal bir tahakküm ile yönetilen her bireyin özgürlük adı altında bir davranış, tavır ve hareketlerinin birer kontrol mekanizmasıyla yönlendirilmesi ve topluma uyum sağlamasına yönelik çalı̧malar yapılması özne olmak veya olmamak kertesinde insanı bağlı kılmıştır. Bu bağlı kılışla birlikte istenen insan ideali ortaya çımış ve kişiler özne olamadan, doğduğu andan itibaren kendisine yöneltilen yaşamı yaşamakta mükellefiyet duyan bireyler haline gelmiştir. Bu manada «uysal» insan tavrı yüceltilmiş ve özgürlüklerin bu uysallıkla var olabileceği düşü insan zihnine yer ettirilmiştir. Bu yazı itibariyle özellikle kendi toplumumuzdaki bireylerin özne olamaması, bu olamayı̧̧ın nedenleri ve özne-iktidar ilişkisinin Haldun Taner'in Gözlerimi Kaparım Vazifemi Yaparım adlı tiyatro oyununda ne şekilde işlendiğinin izlerini sürmek gayretinde olunacaktır. Bu gayret içinde en önemli başucu yazısı olarak Michel Foucault'nun Özne ve İktidar'ından faydalanılacaktır.

\section{1. Çağdaş Dünyada Özne-İktidar Sorunsalı ve Mücadele Üzerine}

Toplumlar yaşamak için mutlaka bir yönetim biçimine ihtiyaç duymuşlardır, bu durum insanın doğal olarak topluluk halinde yaşama isteğiyle yakından alakalıdır. Bu yaşayış tarzı en nihayetinde belirli yönetim şekillerini de doğurmuştur. Giriş kısmında ufakça bahsedildiği üzere ilk yönetim biçimleri genellikle teolojik kökenli ortaya çıkmıştır. Çeşitli medeniyetlerin tarihi üzerine yapılan araştırmalar da göstermektedir ki en fazla rastlanan yönetim biçimi tanr1-kralların olduğu ve tahakkümün elden bırakılmadığı yönetimlerdir. $\mathrm{Hal}$ böyle olunca insanlar ortaya insanüstü özelliklere sahip olduğunu düşündüğü yöneticiler çıkarmış ve mutlak itaat kültürünün gelişmesine ön ayak olmuştur. $\mathrm{Bu}$ durum ilk topluluklarda böyle iken monarşileri ve feodal yapıları kuran 15 ve 16. yüzyıl insanında da aynıdır. Teoloji temelli bir yönetim biçiminden teolojinin kutsal kana indirgenerek belirli aileler etrafinda toparlanmasıyla 
oluşturulan yönetimler düşünce bakımından ilk bahsedilenle pek de farklı değildir. Devir 19. yüzyıla geldiğinde ise teolojinin yerinin olmadığı modern topluluklar kurulmuştur. Lakin bu düzenle birlikte de aklın tahakkümü altında sömürü düzenleri oluşturulmuş ve bu düzenin çarkları içinde toplumu oluşturan bireyler teker teker belirli kalıplara sokulmaya çalışılmıştır. En nihayetinde Foucault bu oluşturulmaya çalış1lan idari sitemler için genel bir tanım yapmıştır:

\begin{abstract}
"Esasen iktidar, iki rakip arasında bir çatışma ya da biriyle öteki arasında bağ kurulmasından ziyade, bir 'yönetim' sorunudur. 'Yönetim’ sözcüğü, on altıncı yüzyılda sahip olduğu çok geniş anlamıyla düşünülmelidir. 'Yönetim' sözcüğü sadece siyasi yapıları ya da devletlerin yönetilmesini anlatmakla kalmıyor, bunun yanı sıra, bireylerin ya da grupların davranışlarına nasıl yön verebileceğini (çocukların, zihinlerin, toplulukların, ailelerin, hastaların yönetilmesi) de gösteriyordu. (...)Bu anlamılla yönetmek, başkalarının mümkün eylem alanını yapılandırmaktır." (2016: 74)
\end{abstract}

$\mathrm{Bu}$ anlamıyla bakıldığında iktidar denilen nosyonun kişiler üzerindeki daraltıcı etkisi görebilir. Bu durum toplumu oluşturan bireylerin özne olmak yolundaki serüvenine bir sekte yaşatmaktadır. Bu sekte yaşanırken bir yandan da istenilen insan profili elde edilmiş olmakta ve genel geçer kavram olarak toplumu oluşturan bireyler tektipleştirilmektedir. Bu tektipleştirmeyi yansıtan bir başka tanım ise yine Foucault' ya aittir:

"İktidar, mümkün eylemler üzerinde işleyen eylemler kümesidir: eyleyen öznelerin davranışlarının kaydolduğu imkân alanı üzerinde yer alır: kışkırtır, teşvik eder, baştan çıkarır, kolaylaştırır veya zorlaştırır, genişletir ya da sınırlar, aşağı yukarı muhtemel hale getirir; uç noktada kısıtlar ya da mutlak olarak engeller, ancak eylemde bulundukları ya da bulunabilecekleri ölçüde eyleyen özne ya da özneler üzerinde bulunma biçimidir. Başka eylemler üzerindeki bir eylem kümesi.” (Foucault 2016: 74)

Bu iki tanımdan da yola çıkarak denilebilir ki iktidar denilen yönetim tahakkümü toplumu oluşturan bireyleri öncelikle sinikleştirir, daha sonra kendi belirlediği sınırlar içinde özgür bırakır. Böylece oluşturduğu kişileri yönetim aygıtı kanalıyla kontrol altında tutar. Bu kendi bekasını koruma yolunda yaptığı en büyük adımdır. 
Modern toplulukların kurulmasıla birlikte yönetim biçiminde yeni bir kavramla karşı karşıya kalınmıştır. Bu kavram tanrı-kralların yönettiği veya kutsallığın indirgenmiş şekilde yaşatıldığ monarşi ve feodalizmden farklı olarak yönetim aygıtının ayağını bu dünya temelli bir yere oturtarak elde etmiş ve kendini geleneksel olandan ayırmı̧ "devlet" kavramıdır. Foucault bu kavramı da kendi içinde yeni bir tanımlamayla yüzyılın sorunu haline getirmeyi başarmıştır: "Bizim toplumumuzda bu tür mücadelenin egemen olma nedeni, on altıncı yüzyıldan beri yeni bir siyasi iktidar biçiminin sürekli gelişmekte olmasıdır. Bu yeni siyasi yapı, herkesin bildiği gibi, devlettir. Ancak çoğu zaman devlet, bireyleri görmezlikten gelen, sadece bütünlüğün ya da yurttaşlar topluluğu içindeki bir sınıfın ya da grubun demeliyim, çıkarlarını gözeten bir siyasi iktidar türü olarak tasarlanır.” (2016: 64) Ortaya koyduğu devlet tanımıla birlikte yeni iktidar türünün de kendini geleneksel argümanlarla çevrelediği fikrini gözler önüne sermiştir. Öyle ki modern devlet olarak ortaya çıkan yönetimlerin aslında nitelik ve özellik bakımından tahakkümcü tavırdan farklı olmadığı aşikardır.

"Modern Devlet'i bireylerin, üstünde onların ne olduğunu hatta varlıklarını görmezden gelerek gelişmiş bir şey olarak değil; tam tersine bireylerin tek bir koşulla dahil edilebileceği -bu bireyselliğe yeni bir biçim verilmesi ve bir dizi çok spesifik örüntüye tabi kılınması koşuluyla- çok gelişkin bir yapı olarak görmeliyiz. Bir bakıma, devleti modern bir bireyselleştirme matrisi ya da pastoral iktidarın yeni bir biçimi olarak görebiliriz." (Foucault 2016: 66)

Tüm bu yönetim tanımlamaları karşısında akılda beliren en önemli olgu, iktidarın bu denli kabuk değiştirerek aynı tavrını devam ettirmesi karşısında toplumu oluşturan bireylerin özne olmak yolunda giriştiği mücadelelerdir. Burada öncelikle mücadele kavramının temelini oluşturan “özne olmak” argümanının iktidarlar tarafindan bertaraf edilmesinin ortaya konması gerekmektedir.

"Bu iktidar biçimi bireyi kategorize ederek, bireyselliğiyle belirleyerek, kimliğine bağlayarak ona hem kendisinin hem de başkalarının ondan tanımak zorunda olduğu bir hakikat yasası dayatarak doğrudan gündelik yaşama müdahale eder. Bu, bireyleri özne yapan bir iktidar biçimdir. Özne sözcügünün iki anlamı vardır: Denetim ve bağımlılık yoluyla başkasına tabi olan özne ve vicdan ya da özbilgi yoluyla kendi kimliğine bağlanmış 
olan özne- ki Gözlerimi Kaparım Vazifemi Yaparım oyunun baş karakteri Vicdani de birinci anlamdan ikinci anlama geçişi görmekteyiz. ${ }^{1}$ - sözcüğün her iki anlamı da boyun eğdiren ve tabi kılan bir iktidar biçimi telkin ediyor." (Foucault 2016: 63)

Görüldüğü üzere özne olma tanımının her iki anlamı da iktidar argümanının bir dayatması halinde ortaya çıkmaktadır. Özellikle farkındalık sahibi insanların birinci anlam karşısında belirli tepkiler gösterdikleri görülse de ikinci anlamın oluşturduğu tahakkümün farkına varmak hayli geniş bir bakış açısı$\mathrm{n}$ gerektirmektedir. Bu durumda yönetim kavramı altında ortaya çıkan tüm tahakkümlere karşı bu kavramları da aşkın bir düşünce yapısı ortaya koyarak tektipleştirici ve bireyselleştirici öznelliğin üstünde bir kimlik inşasına sahip olabilmek elzemdir. Bunu inşanın yolunu yine Foucault' da bulunmaktadır:

"Sonuç olarak şu söylenebilir: Günümüzün siyasi, etik, toplumsal ve felsefi sorunu, bireyi devletten ve devletin kurumlarından kurtarmaya çalı̧̧mak değil; kendimizi hem devletten hem de devletle ilintilidir olan bireyselleştirme türünden kurtarmaktır. Yüzyıllardan beri zorla dayatılmakta olan bu tür bireyselliğin reddetmek yeni öznellik biçimlerine geçerlilik kazandırmak durumundayız." (2016: 68)

Foucault' dan alıntılandığı üzere dayatmaları reddetmek ve bireylerin kendini tahakkümün baskısından sıyırmak için çeşitli mücadele yollarını denemesi modern devlet anlayışının bireylere ön gördüğü bireyleşme kavramını aşarak kendini özne olarak var eden bir yapıya bürünmesine katkı sağlayacaktır. Tüm dünya üzerinde etkili olan iktidar yapıları özne denilen varlı̆̆ı arkadan sararak ve farkına vardırmadan etrafını çevreleyerek var olma alanını kısıtlamaktadir. Bu kisitlayıcilarla birlikte bireylerin var olan ve kendilerine has olan özellikleri de yok edilmektedir. Lakin özne olarak toplumda yaşamak, biri veya birilerinin dayattığı şekle bürünmek değil doğal yaşam içerisinde kendi öz bünyesinde bulduğu cevheri parlatarak ortaya çıkarmak işlemidir. Kişiler bu cevheri ortaya çıkarmak ve toplum aşırı bir özne olabilmek amacıyla çeşitli mücadele yollarını öncelikle kendi bünyesinden yola çıkarak daha sonra aşkın bir toplumsal faaliyet güderek gerçekleştirmelidir. Nitekim Foucault bu mücadele kollarının ortak özelliklerini altı başlık halinde incelemiş ve her birini kendi içinde açıklamıştır. Buradan hareketle özellikle belirttiği

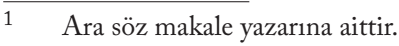


üzere bu mücadelenin bireysel olan kısmı insanlık adına daha spesifik bir hal almaktadır. Ona göre otorite-karşıtı mücadeleler gütmek kişinin özne olma yolunda yaptığı mücadelelerin tamamını kapsamaz bilakis en özgün olarak gördüğü mücadele türleri bireyci olarak ortaya çıkan mücadelelerdir. Verilen mücadele tipi aynı olduğundan mücadeleyi çeşitlemekten ziyade çeşitlenmiş mücadelelerin ortak yanlarına bakmak daha elzem olacağından bunları şu şekilde açıklamıştır: "Bunlar 'sınıraşırı' mücadelelerdir; yani tek bir ülkeyle sınırlı değillerdir. Kuşkusuz bazı ülkelerde daha kolayca ve daha büyük oranda gelişirler, ama tikel siyasi ya da ekonomik yönetim biçimiyle sınırlı değillerdir." (Foucault 2016: 60) Verilen mücadelenin global olarak ortak bir tavırla gerçekleşebileceğinden bahsetmekle kalmayıp dünya üzerinde nerede bir baskıcı tahakküm görülse buraya müdahale etmenin de evrensel ahlakın erdemlerinden olduğu vurgusu önemlidir. Bu vurgu aynı zamanda insanın kendiyle birlikte yaşadığ $\breve{g}_{1}$ toplumu dönüştürmesini de hedeflemektedir. "Bu mücadelelerin amaçlı, oldukları haliyle iktidar etkileridir. Örneğin, tıp mesleği esas olarak kar güdüsüyle hareket eden bir alan olduğu için değil; insanların bedenleri, sağl1kları, yaşamları ve ölümleri üzerinde hiçbir şekilde denetlenmeyen bir iktidara sahip olduğu için eleştirilir." (Foucault 2016: 62) Gerçekleşen mücadelelerin aslında iktidarın görevini yerine getirmemesinden ziyade anlamını başka kavramlara kotararak yaptığından meydana geldiğini söylemekle birlikte özne ile iktidarın birbirini baskılama unsuru olarak gördüğünü bunun aslında iktidar temelli bir yanlı etkileşimden fidan aldığını dile getirmek önemli bir noktada durmaktadır. "Bunlar, iki nedenle 'doğrudan’ mücadelelerdir. Bu tür mücadelelerde insan kendilerine en yakın olan, eylemleriyle bireyleri etkileyen iktidar mercilerini eleştirirler. 'Baş düşman' yerine doğrudan düşman arayışına girerler. Sorunlarına gelecek bir tarihte çözüm (yani, özgürlük, devrim, sınıf mücadelesinin bitmesi gibi) bulmayı da ummazlar." (Foucault 2016: 62) Dünya üzerindeki en büyük problemlerin başında gelen bir baş düşman edinme düşüncesi insanları bir masa etrafinda tartışmaktan, bir tez-antitez-sentez yapmaktan alıkoyduğu düşünüldüğünde yapılan mücadele sonucunda ortaya hâlâ birey olamayan kişilerin serzenişlerinin çıkması gayet doğaldır. Mücadele ruhunun öncelikle iktidar denilen aygıtın yöntemiyle değil kendi özne olma yolunda oluşturulan yöntemlerle sağlanması bireyleri yapmaya çalıştı̆̆ı tefekküre daha yaklaştıracaktır. "Bunlar bireyin konumunu sorgulayan mücadelelerdir. Bir yandan, farklı olma hakkına sahip çıkar ve bireyleri hakikaten birey yapan her şeyi vurgularken, öbür yandan bireyi parçalayan, başkalarıyla bağlarını koparan, cemaat yaşamını bölen, bireyi kendi üzerine kapanmaya zorlayan ve kısıtlayıcı bir biçim- 
de kendi kimliğine bağlayan her şeye saldırırlar.” (Foucault 2016: 62) Bireyin toplum içindeki yapıp etmelerinden hareketle yer ve yurt edinmesinin ya da edinememesinin toplumla kurduğu bağlar açısından önemi ortaya çıkar. $\mathrm{Bu}-$ nunla birlikte kişilerin özne olma yolunda baskı altına alınmak istenen insani özelliklerini ortaya çıkarmak amacıyla güttüğü mücadelenin en keskin biçimi kendine kapanmasıdır. Buna karşılık "açılma” fiilini gerçekleştirmesinin olası en muhtemel davranı̧̧ olduğu göz ardı edilemez.

"Bunlar, bilgi, beceri ve kalifikasyona bağlı olan iktidar etkilerine karşı bir muhalefet, yani bilginin ayrıcalıklarına karşı yürütülen mücadelelerdir. Ama aynı zamanda, gizliliğe deformasyona ve insanlara zorla dayatılan gizemselleştirici temsillere karşı yürütülen mücadelelerdir de.” (Foucault 2016: 62) Bilginin saklanıp gizlenmesi veyahut sadece belirli bir zümrenin nesnesi haline getirilmesi bireylerin özne olma yolunda kısıtlanması anlamına gelmektedir. Nitekim Orta çağda teolojik temelli bir yönetim bulunması ve bu yönetimin kendi bekasını uzun yıllar sürdürmesi bahsedilen duruma aittir. İncil'in okunmamasıyla birlikte sadece belirli bir kesimin okuması var olan toplum düzeninde efendi-köle ilişkisini desteklemektedir. Hal böyle olunca o toplumu oluşturan bireyler özellikle köle öznesinde kendini inşa eden bireyler olamamaktadırlar. "Son olarak, halen varlı̆ğ sürdüren bütün bu mücadeleler şu soru ekseninde dururlar: Biz kimiz? Bunlar, bizim bireysel olarak kim olduğumuzu göz ardı eden soyutlamaların, ekonomik ve ideolojik devlet şiddetinin reddedilmesine ve gene, insanların kim olduğunu belirleyen bilimsel ya da idari engizisyonun reddedilmesidir." (Foucault 2016: 63) Tüm mücadelenin temelinde duran ve yazının daha yukarılarında sorulan açmazın aslında cevabı burada gizlidir: “ Biz Kimiz?”. Yaşanılan toplum içinde bireylerin konumlanışı elbetteki tüm hayatını etkilemekte ve bu durum evrensel ahlakın, insani duruşun onları ne anlamda etkilendiğine cevap niteliğindedir. Eğer bireyin verdiği cevap bütünün sesi olmuş olmak ise özne olamayışının da bir serzenişidir, eğer ki cevap kendi öznesinin sesi olmuş olmak ise özsesini yakalayarak özne olmuş demektir.

\section{Gözlerimi Kaparım Vazifemi Yaparım'da İktidar Kavramının İzleri}

Haldun Taner'in göstermeci tiyatro adı altında kaleme aldığı eseri, aslında bir nevi iktidar tahakkümünün değişmezliği üzerine inşa ettiği ve Vicdani öznesinde bu tahakkümün çeşitlerini gözler önüne serdiği yapıtıdır. Bu durumu Ayşegül Yüksel özetler nitelikte: "Gözlerimi Kaparım Vazifemi Yaparım, değişen güncel görünümlerin gerisindeki değişmezliğin öyküsüdür. Değiş- 
mezlik, politik ve toplumsal düzeyde görülen değişikliklere karşın, toplum yapısının, toplum yapısına bağlı olan olarak da insanın yapısının, temelde değişime uğramayışından kaynaklanır." (2013: 73) diyerek aslında toplumlar değişimle birlikte yeni yaşam düzenleri ve "yönetim" biçimleri kursalar da özde değişmediklerini ve her birinin aleni olarak görünmese de tahakküme el verir nitelikli oluşlarını dile getirmiştir. Eser, baş karakter Vicdani'nin doğumuyla başlayarak hayatı içinde kendisine yaşattırılan tüm baskının ortaya konması, bir bireyin toplumda kendi sesini ne kertede bulacağını da göstermek amacıyla bilinçli olarak yazılmıştır. Vicdani'nin daha üç aylıkken annesini kaybetmesi ile başlayan aile serüveni biraz sonra babasının da ölmesiyle başlamadan sona erer. Aslında bu durum Vicdani'yi bir anda hayatın içine atmakla birlikte, hayata tutunmak amacıyla kişiliğinin de erken gelişmesine neden olmuştur. Bu manada hayata tutunmak amaciyla kendi bilincini inşa edemeden dayatılan "özne” olmak zorunda kalmıştır. Nitekim Vicdani okul yıllarına geldiğinde iktidarın öznesi olan hoca efendiden "istenilen özne” nas1l olunur öğrenmiştir:

"Hoca: Berhudar ol. (Vicdani'ye) Sen de öp elimi. El öpmeyle ağız aşınmaz. / Vicdani: Öpeyim efendim. (Koşup Öper.) / (...) Hoca: (Vicdani'ye) Sen şimdiye kadar hiç falakaya yedin mi? Öp elimi. / Vicdani: Yemedim efendim; ama sizin mübarek elinizden yerim inşallah efendim. (Elini öper.) Hoca: Elif sin le esa is./ Vicdani: Elif sin le esa is./ Efruz: Herif ile seyis. / Hoca: Herif ile seyis değil (Tokat Atar. Efruz eğilir, tokatı Vicdani yer.) Elif sin le esa is. Buna vurdum, sen yedin. Ama zararı yok. Hocanın vurduğu yerde gül biter. Te sün te. / Vicdani: Te sün te. / Hoca: İste. / Efruz: Ver. (Elini uzatır.) / Hoca: Değil efendim, iste. / Efruz: İstedim ya. / Hoca: (Bir tokat daha atar, aynı şekilde Vicdani yer.) Şimdi birlikte okuyun. / (...) Hoca: (Taş tahtaya eski harflerle uysal kelimesini yazar.) Aferin, elif vav sin, elif lam. Ne eder? / Efruz:( Hesap eğitimi için kullanılan küreleri sıralar.) İki iki daha dört eder. / Vicdani: Uysal eder hoca efendi. / Hoca: Uysal olun çocuklar, uysal. Keskin sirke kabına zarar." (Taner 2015: 19-20).

“İstenilen özne» nin uysal olma özelliğini öğrendikten sonra cismi varlığının dünya üzerindeki kifayetinin de iktidar tahakkümünden geçmesi de gerekmektedir. 
"Hoca: Gelelim iskelete: İskeletin iki eli var, ne için? / Efruz: Oynamak için. / Cemalifer: Dikiş dikmek için. / Vicdani: (Sabırsızlık içinde) Söyleyeyim mi? / Hoca: Söyle/ Vicdani: (Otomatik) Çalışmak için. Çalışan kazanır. Çalışmak insanı hayvandan tefrik eder. Çalışan çocukları büyükleri pek sever. / Hoca: İnsanın bir kafası var. (Sopa ile gösterir.) Ne için? Sen söyle Efruz./ Efruz: Kolalı fes giymek için. / Hoca: Sen söyle./ Vicdani: Düşünmek için hoca efendi. / Hoca: Aferin! Amma./ Üçlü Koro: Amma çok düşünmek de iyi değildir. İnsanın kafasına zararlı fikirler üşüşür. Büyükler her şeyi bizden iyi düşünür. / Hoca: Son cümleyi tekrarlayın. (Orkestra şefi gibi tekrarlatır.) / Üçü Koro Halinde: İnsanın kafasına zararlı fikirler üşüşür. Büyükler her şeyi bizden daha iyi düşünür. / Hoca: (Sopa ile iskeletin gözlerini gösterir.) İnsanın iki gözü var. Ne için? / Cemalifer: Görmek. / Hoca: Bir ağzı var. / Efruz: Konuşmak. / Hoca: İki kulağı var. / Vicdani: İşitmek için. / Hoca: Ama biz ne yapmalıyız? / Üçü Koro Halinde: Kötü şeylere karşı gözümüzü yummalı, sağır olmalı, dilimizi yut-ma-l1-yız./ Hoca: Şimdi hayvanat dersine geçebiliriz. (Devekuşu resminin göstermeliği iner.) / Hoca: Bu ne kuşudur? / Vicdani: Bu bir devekuşudur. / Hoca: Devekuşu nasıl bir hayvandır? Devekuşu hayvanların şahıdır. / Koro: Devekuşu çok sevimli bir hayvandır. Devekuşu hayvanların şahıdır. / Hoca: Aferin.” (Taner 2015: 23-24)

İnsanın dünya üzerindeki varlı̆̆ından bahsedilmesi gerekirse akla ilk gelen özellikleri sayılmakla birlikte bunları güdümlü bir şekilde kullanmak gerektiğini de bizlere söyleyen anlatıcı, iktidarın aynı zamanda insanın önemli özelliği olan düşünme yetisini de bir baskı altına almayı hedeflemesini hissettirmektedir. Çünkü toplum içinde sözde bir huzurla yaşamanın yegâne şartı akan, değişen, dönüşen dünyaya karşı değişmeyen olarak kalan ve tüm bunlara karşı kafayı kuma gömen bir özne olmaktan geçer.

“Vicdani, tıpkı Memnun gibi, acıtan gerçekleri görmemek amacıyla kafasını kuma sokmuş ama gövdesini tüm tehlikelere açık bırakmı̧̧ bir devekuşudur... Vicdani, toplumsal ilişkilerimiz bağlamında çok önemli bir koşullanmışlı̆̆ın canlı göstergesini oluşturur: Gerçeklere düşünerek ulaşmaktansa, onları hep kendisine belletildiği biçimde benimsediği için kolayca aldatılan ve ezilen, kişiliksiz, küçük adamdır... Kendine güveni olmayan, tek güvenceyi, geçerliliğini tartışmayı aklından bile geçirmediği kurallara uymakta bulan Vicdani, bir bakıma etkin azınlığın içinde gittiği edilgen çoğunluktur." (Yüksel 2013: 75) 
Özne- iktidar ilişkisinin insanların toplumsal yaşamlarına olduğu kadar kişisel yaşamlarına da sirayet ettiği bilinmektedir. Bununla birlikte toplum için istenen özne olmanın yolu kayıtsız şartsız bir fedakârlıktan geçmektedir. Bu fedakârlık bazen bireyin kendi benliğinden bazen en değer verdiklerinden bazen de duygularından vazgeçmek olabilmektedir. Lakin tektipleşen özne, fedakârlıkla kaybetmek arasındaki nüansı kaçırarak çoğu zaman kendi benliğinden farkında olmadan da olsa ödün vermektedir.

"Cemalifer: Sen benim için ne fedakârlık yaparsın? / Vicdani: Ne istersen! Ne istersen! / Cemalifer: Canını verir misin? / Vicdani: (Düşünür) Bak, şey. Ben canımı vatanıma adadım! Sen başka bir şey iste. / Cemalifer: Neyini, neyini? / Vicdani: Siyami’den aldığım Sultan Reşat pulunu veririm. / Cemalifer: Aman, ben pulu ne yapayım? / Vicdani: İki çocuğun on iki ciltlik devrialem seyahatini veririm, oku. / Cemalifer: İşin mi yok! Onu sen kendin oku. / Vicdani: Aman, ne vereyim sana kardeş, aa.../ Cemalifer: Sen de o Tobler'den çıkan bayrakları biriktiriyor musun? / Vicdani: Ben onlardan hiç yemedim ki biriktireyim. / Cemalifer: Bende hepsi tamam da bir Çin bayrağı eksik. Bir onu bulsam.../ Vicdani: Ne olacak onu bulsan? / Cemalifer: Hepsi tamam olunca kol saati hediye ediyorlar. / Vicdani: Kol saatini çok mu istiyorsun? / Cemalifer: hımmmm. / Vicdani: (Çıkar) / Cemalifer: Nereye? / Vicdani: Ne yapıp yapıp sana Çin bayrağını bulacağım kardeş. / (...) Vicdani: Cemalifer, Cemalifer, bütün pul koleksiyonumu satıp sana Çin bayrağını buldum. / Cemalifer: (Birden ağlaması durur, bayrağı kapar.) sen dünyanın en iyi kalpli çocuğusun Vicdani. (Yine ağlamaya başlar.) Ama ben yine o keşkem suratlı Efruz'u seviyorum, ne yapayım elimde değil. (Ağlar)/ Vicdani: Ağlama kardeşim. (O da ağlamaya başlar.)" (Taner 2015: 31-32/ 34)

Vicdani, istenen özne olabilmek adına iktidar karşısında tüm dayatmaları kabul etmiş ve en değerlilerinden ödün vermiştir. Bu ödün verişin sonunda ise yine benliğini inşa edememenin üzüntüsünü yaşamıştır. Vicdaninin çocuk yaşta hoşlandığı birinden aldığı bu ilk yenilgi gelecekteki yaşamına da tevarüs edecektir. Nitekim evlilik hayatında yaşadığı hezimet de bunu gösterecektir ki istenen özne olmak yolunda yapılan her davranış kişinin kendi benliğinden vazgeçtiği önemli bir hasletidir. Çalıştığı yerdeki bir kıza safiyane duygular besleyen Vicdani, aslında kızın patrondan hamile olduğunu bilmeden onun- 
la bir anda evlenmek zorunda kalmıştır. Karnındaki çocuğu evlilik kurumunun koruyucu kalkanıyla gizleyen Lalifer, evlendikten sonra da eski hayatını bırakmamış ve yine patronuyla gayrı meşru ilişki yaşamaya devam etmiştir. Vicdani'nin bir iş seyahatine çıkması esnasında uçağın Erzincan depreminden dolayı kalkmaması esrar perdesini aralayacak bir olaya sebebiyet vermiştir. Eve tekrar döndüğünde patronu ve karısını evde yakalayan Vicdani en başta öğretmeninin ona öğrettiği üzere "uysal” olarak bu durumu karşılamış, işinden ve eşinden ayrıldığını yine tahakkümün kıstığı sesle dile getirmiştir. "Vicdani: Serini sıcağı yok karıcı̆̆ım. Affınıza mağruren derhal işimden ayrılıyorum. Seni de vefakâr karıcığım, bundan böyle bu tip hareketleri rahatça yapabilmen için hürriyetine kavuşturuyorum." (Taner 2015: 62) Tüm bunlara rağmen iktidar dilini kullanan patron yaptığı ahlaksızca davranışı bir kenara bırakarak bir kapital tavrına bürünüp iş yerindeki bordro işlerinin bırakılamayacağını, bu davranışın yarıda bırakıp gitme olduğunu dile getirmektedir. Vicdani bu durum karşısında kendi müdafaa etmek yerine istenen özneye yakışır şekilde davranarak: "Vicdani: Hak yok vazife vardır diyor. Birkaç gün için şahsi duygularıma gem vuracağım. Bordroları tanzim edip, üç yüz aileyi, firmayı ve cemiyeti ve de milli menfaatleri koruyacağım. Ama ondan sonra affınıza mağruren firmadan da karımdan da ayrılacağım.” (Taner 2015: 63) kendi benliğinden ödün vermiş ve benliğini inşa edememiştir. Özne-iktidar bağlamında kişisel ilişkilerde kendini özne olarak konumlandıramayan Vicdani, toplumsal ilişkilerde de "özne” olamayıp özgünlük kazanamamıştır. Nitekim iş görüşmesine gittiğinde işveren/iktidar olan kişi kendi istek ve arzularını daha Vicdani'ye söylemeden o, kendinden iktidar tahakkümünü hissettiğinden ve bunu hayatının bir parçası gibi görüp yadırgamadığından direkt bir eşyaymış gibi kendinden bahseder:

"Vicdani: Sakinim efendim. Kumarım, illetim, sefahatim yoktur. Pazarları bile çalışırım. Hiç değilse evdeki bozuk muslukları, masaları, saatleri tamir ederim. İlan buyurduğunuz sekreterliğe layık miyım, bilmiyorum. Daha ehil bir kimse varsa onun ekmeğini almak asla aklımdan geçmez. Ama beni almak inayet ve teveccühünü gösterecek olursanız o zaman fedakârane, cansiperane çalı̧ıırım. Allah'a şükür kanaatkâr bir insanım. Bir lokma bir hırka. Ne verseniz kabulüm. Politikadan nefret ederim. Bir memur kendi başına siyasi muhakemeler yürütmeye başladı mı o memlekette anarşi başladı demektir. Allah bizi o günlerden korusun. Âmin efendim. Dedikodudan, çalçenelikten de hoş- 
lanmam. İş, gönüller rahat olsun, değil mi efendim? İnsan yurduna ve amirlerine faydalı olduğunu bir an için vicdanının köşesinde hissetsin. Yeter efendim yeter, yeter. Gözlerimi kaparım Vazifemi yaparım.” (Taner 2015: 49)

Aslında bir nevi yazının başında bahsedilen Foucault'nun özne tanımının birinci kısmına uyan Vicdani’nin bu tanımı kendi öznesinde özne olamamış tüm bireylerin sesi ve tanımı olmuştur. Tüm bu özelliklerine rağmen girdiği bu iş yerinde yukarıda bahsettiğimiz talihsiz evlilik olayını yaşamış ve ayrılmış, buradan sonra çocukluk arkadaşı olan Efruz' un gazete bürosunda Mahzun Kalpler Sütunu' nu yazmak üzere işe alınmıştır. Buraya alınma sebebi de aslında yine iş için yeterliliğ̆i değil tamamıyla iktidarın kendi içini "öteki” benliğinden rahatlatması amacıyla olmuştur. "Yazı İşleri Müdürü: Bunu niye aldınız patron? / Efruz: Aramızda bir de temiz vicdanlı adam bulunsun diye. Bir nevi nazar boncuğu gibi. Belki uğur da getirir bize.” (Taner 2015: 73) Bahsi geçen temiz vicdanlılık yine Vicdani’nin başına bela olacaktır. Efruz'un karısına/metresine gönderdiği şantaj mektuplarını Vicdani’ nin masasındaki çekmeyeceğe koyması yüzünden- ki ondan bu umulmayacağ1 için kontrol edilmeyeceğini düşünüyor- tevkif edilmesi ve bu yüzden hapse girmesi söz konusu olacaktır. Bu durum meydana geldiğinde bile kendini savunurken "iktidar" dilini kullanarak kendini savunmaya çalışmaktadır.

"Emniyet Müfettişi: Önceki İşlerin? / Vicdani: Her İş Üzerine Ticaret Şirketi Müfettişi. Beni niye getirdiler, hiç anlamadım. Vatan cephesine girmekse hepimiz girdik. Şair bile ne demiş, değil mi efendim: 'Vatan bizim canımız feda olsun kanımız.' Nerde vatan lafı görsem, bendeniz oradayım. Benim hiçbir siyasi görüşüm yoktur. Devletimin, hükümetimin resmi görüşü ne ise, benim görüşüm de odur. Ben sabahleyin kalkarım, radyoyu açarım. Anadolu Ajansı, ne buyururlarsa durumumu ona göre düzenlerim memur bey." (Taner 2015: 81)

Kendini iktidarın diliyle de savunsa isnat edilen suç üzerine kalacağından hapishaneye girecek olan Vicdani, hâlâ bu durumun başına neden geldiğini anlayamamaktadır. Çünkü öğrendiği üzere insanda kafa düşünmek için vardır lakin düşünmesinin sınırı iktidarın belirlediği ölçüdedir. Kendiyle beraber tevkif edilen arkadaşı/patronu Efruz, iktidarın tüm kollarını kullanabildiğinden ve taraf olabildiğinden hapishaneden kurtulmuş, Vicdani'yi ziyarete gelmiş onu kurtaracağını dile getirmiştir. Vicdani hâlâ neden kendisinden 
böyle bir konu için şüphe edildiğini merak etmektedir. Efruz'un itirafiyla aydınlanan zihni aslında arkadaşının suçunun cezasını çektiğini fark edemeden Efruz'un kullandığı eril dilin etkisiyle hapishaneden çıkmaya odaklanmıştır. $\mathrm{Bu}$ durum yine haksızlığa uğramış olsa da bunları sorgulamayan ve istenen özne olmaya devam eden bir yapı sergilemesini sağlamı̧̧ır. "Vicdani: Vallaha bu iyiliğini nasıl ödeyeceğimi bilemiyorum, Efruz. / Efruz: Lafi mı olur kardeşim? Kaldı ki benim yüzümden girmiştin bu belaya. / Vicdani: (birden hatırlamıştır.) Sahi o da var ya." (Taner 2015: 84)

Vicdani, hapse girdikten sonra kendi bilincine kapanmakla birlikte hapisten çıktıktan sonra kendini sorgulamaya başlar. Yaşadığı kovuşturmalar, isnat edilen suçlar ve yaşadığı dönemin siyasi-tarihi etkisiyle yaşadıklarını kendinden kaynaklanan bir neden de arar, ayrıca tüm bu yaşadıklarından sonra birileri tarafindan takip edildiğini düşünür. "Vicdani: Emin ol tebdil. Bir suçum var Efruz. Bilmediğim bir suçum olmalı. Yoksa niye peşime düşsünler." (Taner 2015: 95) Bu durum kendisinde bir paranoya yaratacak hale geldiğinde bir nevi sistemin dişına itilmek istenircesine tatil yapmak için Yalova'ya gönderilmiş fakat orada da takip edildiğini düşündüğünden tekrar geri evine/kendine dönmüştür. Kendini sorgulamaya devam eden Vicdani, sorunun kendi benliğinde var edemediği ve ötekileştirdiği öznesi olduğunu fark eder. "Sarhoş: Az beri bak arkadaşım. Ne arıyorsun buralarda? / Vicdani: Birini yakalayıp sorguya çekeceğim. / Sarhoş: Kim bu kovaladığım adam? / Vicdani: Öteki. / Sarhoş: Hangi öteki? / Vicdani: İçimdeki öteki. Yani ben kendi kendimin peşindeyim.” (Taner 2015: 98) Tam kendi benliğinin farkına vararak "Özne" yi inşa edeceği sırada iktidar tarafından fark edilir ve tahakküm mekanizması devreye girer. Bir akıl hastanesine yatırılan Vicdani burada kontrol altında tutulmaya çalış1ılı. Bu kontrol altında tutuş aslında iktidarın refleksif bir hareketidir. Çünkü kendi benliğinin farkına vararak öznesini inşa eden insan mücadele ruhunu bünyesinde hissedecektir ve bunun için çalı̧̧malara başlayacaktır. Akıl hastanesinde Vicdani'nin muayenesi sonucu vardığı bulgular ve doktorun Vicdani’yi adlandırdığı kavram özne-iktidar ilişkisi açısından önemlidir. Öncelikle Doktor Vicdani'yi “süje” olarak kavramlaştırmaktadır. Süje kelime itibariyle özne olarak çevrilse de anlam olarak Foucault'nun yukarıda alıntılanan özne tanımının ilk kısmına girmektedir. Yani denetim ve bağımlılık yoluyla başkasına bağlı olarak yaşayan varlık anlamına gelmektedir. Akıl hastanelerinin ortaya çıkışıyla hastaların kontrolünün sağlanmasının yanında aslında bireylerin özneleşmesi engellenerek iktidarın bekası sağlanmış olacaktır. Daha sonra doktorun Vicdani'yi muayene ettikten sonra bulduğu bulgulardan bazıları önemli ipuçları vermektedirler. "Doktor: 
Yaz asistan efendi, ideosiye (Kavrama ve anlama yeteceğinin olmamasıly belirgin durum, zekâ geriliği.) Yakın aşağılık kompleksi. / (...) Yaz asistan efendi, demansiya prokosiya (Nedeni bilinmeyen, sağlıklı bir mental ve zihinsel gelişme döneminden sonra giderek bu işlevlerde gerilemenin başlaması ve kişilik bozukluğu gibi belirtilerin ortaya çıkması durumu.) alameti." (Taner 2015: 100-101) Bu bulgular da göstermektedir ki kendi benliğinin farkına vararak özne olmayı hedefleyen bireyler iktidar tarafindan zekâ geriliği ve kişilik bozukluğuyla karşı karşıya bırakılmaktadır.

\section{Vicdani Öznesinde Mücadele}

"Son olarak, hâlen varlığ1 sürdüren bütün bu mücadeleler şu soru ekseninde dururlar: "Biz kimiz? Bunlar, bizim bireysel olarak kim olduğumuzu göz ardı eden soyutlamaların, ekonomik ve ideolojik devlet şiddetinin reddedilmesidir ve yine insanların kim olduğunu belirleyen bilimsel ya da idari engizisyonun reddedilmesidir." (Foucault 2016: 63) Bu alıntıyı tekrarlayarak Vicdani'nin biz kimiz sorusuna verdiği cevapla aslında Foucault'nun ortaya koyduğu mücadele yöntemlerinin en temel olanını yerine getirip getirmediğine bakılması gerekmektedir. Kendi benliğinin farkına sorular yoluyla varmış ve bunun sonucunda akıl hastanesine bile göz yumacak hale gelen Vicdani kendi benliğinin sesini dinlemiştir. Dolayısıyla mücadele ruhunu bünyesinde hissedip özsesini bularak öznesini inşa etmiştir. Hayatı boyunca toplumdan yetim ve ezilen olduğu için soyutlansa da onurlu ve namuslu olarak çalışmış biri olarak ekonomik tahakkümle karşı karşıya kalsa da toplumsal ilişkilerin idari anlamda düzenlenmesinden kaynaklı duygularından ve aklından olsa da sonunda “Ben kimim?” sorusuna verdiği “ öz bilgi yoluyla kendi kimliğine bağlanmış bireyim” minvalindeki cevabı onu mücadele bağlamında varsıl kılmıştır.

"Vicdani: Burası Bakırköy'de bir hastane/ Ben 399 no'lu hasta/ Teşhis: Plak kompleksi/ Marka: Sahibinin Sesi/ Bir iğne görmez miyim/ Firıl firıl dönerim/ Yolunuz buraya düşerse/ Bana plak firçası getirin/ Ben insanları çok severdim/ Çok severim/ $\mathrm{Ne}$ var ki sevdiğim kadar/ Sevilmedim/ Çok saftım bir zamanlar/ İnandım kandırıldım/ Vatanıma, karıma, vazifeme/ Amirlerime, dostlarıma/ Köpek gibi sadıktım/ Belki bundan ötürü/ Köpek sayıldım/ Yetmişime bir yaş kala/ Teşhisimi koydular/ Tam uyanacaktım/ Bütün saçma şarkıyı/ Bir baştan sona çizip/ Kendi şarkıma başlayacaktım/ Müsaade etmediler/ Bana deli dediler/ Ben şimdi geceleri/ Bütün şehir uyurken/ Gözümü hiç 
kırpmıorum/ Tıpk1/ Koza ören ipek böceği gibi/ Mırıl mırıldan/Yeni bir plak/ Dolduruyorum/ Sir / Sizinle benim aramda/ Aman doktor duymasın/ Bu seferki plağın adı/ Sahibinin Sesi değil/ Vicdani’nin öz sesi/ Bütün dünyaya karşı/ Yüzyıllardır kandırılmış/ Ezilmiş/ Okkanın altına gitmiş/ Küçük adamların/Uyanı̧̧ marşı." (Taner 2015: 105-106) 


\section{SONUÇ}

Haldun Taner'in özne ve iktidar bağlamında kendini var eden fakat bu var oluşun acılarını çeken öznesi olan Vicdani’nin özne olma yolundaki serüveni aslında farkındalık sahibi olan bireylerin çoğunun yaşadığı bir olgudur. $\mathrm{Bu}$ olguyu bireyin benliğine ait seslerle yoğurarak kendini var etmesi yani özne olduğu bir yaşam olgusu kertesine getirmesi elzemdir. Göstermeci bir tiyatro olan Gözlerimi Kaparım Vazifemi Yaparım bu anlamda hem daha yaşanılası bir dünyanın nasıl olması gerektiğiyle alakalı kapıları aralamakta hem de Foucault'nun bahsettiği iki özne tanımının geçiş evresini gözler önüne sermektedir. Asıl olması gereken tanımın 1şığında düşünülürse dünya üzerindeki tüm tahakkümlere mücadele ruhuyla mukabele edilmesi de bireylerin kendini inşa etme yolunda adım atan özneler olarak var olmasını sağlayacaktır. Fakat bu var oluş bireyin toplumdan vazgeçişi anlamına da gelmektedir. İstendik özne olmamak bir başka deyişle toplumsal normları kabul etmemek karşısında özsesi duyan ve haykıran birey olmak acı verici de olsa yalnızlığ1 kabul edip gözleri kırpmadan kendi şarkısını söylemek manasına gelecektir.

\section{KAYNAKLAR}

Çelebi, Vedat (2013). "Michel Foucault'da Bilgi, İktidar ve Özne İlişkisi”, Sosyal ve Beşerî Bilimler Dergisi, Cilt: 5, No:1, sf. 512-523.

Foucault, Michel (2016). Özne ve İktidar, Çev. Iş1k Ergüden, İstanbul: Ayrıntı Yayınları.

Spivak, Gayatri Chakravorty (2016). Madun Konuşabilir mi?, Çev. Dilek Hattatoğlu- Gökçen Ertuğrul, Ankara: Dipnot Yayınları.

Taner, Haldun (2015). Gözlerimi Kaparım Vazifemi Yaparım, İstanbul: Yap1 Kredi Yayınları.

Yüksel, Ayşegül (2013). Haldun Taner Tiyatrosu, İstanbul: Habitus Yayınları. 
